\title{
CAESARS AND MISOPOGON: A LINGUISTIC APPROACH OF FLAVIUS CLAUDIUS JULIANUS' POLITICAL SATIRES.
}

\author{
Georgios Alexandropoulos \\ George.Alexandropoulos@aol.com
}

\begin{abstract}
This study examines the linguistic practice of two political satires ${ }^{1}$ (Misopogon or Beard - Hater and Caesars) written by Flavius Claudius Julian $^{2}$ the Emperor. Its purpose is to describe the way that Julian organizes the coherence and intertextuality of his texts and to draw conclusions about the text, the context of the satires and Julian's political character.
\end{abstract}

\section{INTRODUCTION}

Misopogon or Beard - Hater ${ }^{3}$, is a satirical essay and Julian's reply to the people of Antioch who satirized him in anapestic verses and neglected his way of political thinking. The political ideology he represented was repelled by the Syrian populace and the corrupt officials of Antioch. Caesars is a Julian's satire, in which all the emperors reveal the principles of their character and policy before the gods and then they choose the winner.

Julian writes Caesars in an attempt to criticize the emperors of the past (mainly Constantine) whose worth, both as a Christian and as an emperor, Julian severely questions. He writes Misopogon when he decides to begin his campaign against the Persians. When he tried to revive the cult relative to ancient divine source of Castalia at the temple of Apollo in the suburb of Daphne, the priests mentioned that the relics of the Christian martyr Babylas prevented the appearance of God. Then Julian committed the great error to order the removal of the remains of the altar and thus they were accompanied by a large procession of faithful Christians. Shortly thereafter, the temple of Apollo was destroyed by fire and Julian, hastily throwing responsibility on Christians, ordered severe interrogations. In addition, he closed the largest church in the city, before the investigations prove that the fire was actually an

1 For the translation of the letters we rely on Wright (1998) and on http://en.wikisource.org.

2 For more information about his life see Athanassiadi (1992), Baker-Brian \& Tougher (2012), Bouffartigue (1992), Fouquet (1985), Smith (1995), Tougher (2007). 
accident (Potter 2004:515). His relations with the Antiocheans got worse after a severe food shortage. Julian tried to stabilize the price of wheat imported from Egypt. It was then when the producers refused to sell theirs claiming that the harvest was bad and therefore they should be compensated by higher selling prices for their product. Julian accused them that their practices lift the prices and forced them to sell. The Antiocheans got furious with him and did not follow his policy. For this reason, he writes Misopogon satire, in order to blame them for their behavior. Through these texts Julian, as a manipulative political orator, expresses his antithesis to what happened and still happens in this period of time in the specific area. His language choices reflect his political thought and the purpose of these speeches is to criticize and promote the emperor's political view. This will be revealed through our analysis.

In the present paper, the rhetorical ${ }^{4}$ practice of these satires is going to be examined by adopting specific models. Julian's political satires will be examined according to the guidelines of discourse analysis as a language practice proposed by Fairclough (1992:78-87), which are: a) the force of speech, (eg. speech acts to persuade, to denounce, to compliment, etc.), b) the coherence $^{5}$ of the text (eg. rhetorical relations) and c) the intertextuality ${ }^{6}$, namely the incorporation of other texts in each satire.

The coherence of Julian's satires will be analyzed through the Mann \& Thompson Rhetorical Structure Theory (1988), in order to draw conclusions about the communicative goal of these texts. For this reason, Hymes (1974) context theoretical model and Searle's categorization ${ }^{7}$ (1969; 1979; 1994;

${ }^{4}$ For rhetorical practice in Byzantium see Hunger (1978).

${ }^{5}$ For more information about coherence see de Beaugrande \& Dressler (1981), Mann \& Thompson (1986 1988), Hoey (1993) and Winter (1977), Mann and Thompson (1986 1988) and Mann et al. (1992) propose some rhetorical relations (circumstances, solutionhood, elaboration, cause, result, purpose, condition, interpretation, evaluation, restatement, summary, sequence, contrast, motivation, antithesis, background, enablement, evidence, justify, concession, joint) expressed in any kind of text. These relations can describe the speakers' rhetorical organization in a different way, as the Rhetorical Structure Theory can focus on the rhetorical goal of the text combining the total of its relations. These relations are divided into two spans: nucleus and satellite or nucleus and nucleus. The role of the context and the speech acts can also play important role in the interpretation of the choice of the particular rhetorical relations in each text. The functions of these rhetorical relations are a product of the speaker's intentionality and give the opportunity to the hearer to discover how the parts of this text can be combined with each other for a certain purpose.

${ }^{6}$ For more information about intertextuality see de Beaugrande \& Dressler (1981), Bakhtin (1981· 1986·1993), Kristeva (1980), Riffaterre (1978·1983·1990).

${ }^{7}$ For Searle $(1969 ; 1979 ; 1994 ; 1996 a, b)$ we have assertive speech acts: speech acts that commit a speaker to the truth of the expressed proposition, directive speech acts: speech acts that are to cause the hearer to take a particular action, commissive speech acts: speech acts that commit a speaker to some future action, expressive speech acts: speech acts that express the speaker's attitudes and emotions towards the proposition 


\section{VOLUME 8}

1996a, b) of speech acts are adopted. For the study of intertextuality, through an approach of Critical Discourse Analysis, ${ }^{8}$ that is, the Discourse Representation proposed by Fairclough (1992), Caldas-Coulthard (1997) and Alexandropoulos (2013) in order to discover the new functions that texts acquire, when they are incorporated into new texts. Bazerman \& Prior (2004) model is also adopted in the attempt to understand the functions of the intertextual source after the recontextualization such as support, proof etc.

What findings can contemporary linguistic theory bring to bear on Julian's writings which the rhetorical treatment of such texts using models germane to the fourth-century are not able to do? The above methodology is going to give us the opportunity to draw some conclusions about the stylistic way that Julian uses his speech, in order to create ideological social nets and divide the people into two groups, the good and the evil (into the selected passages of his texts).

\section{COHERENCE: RHETORICAL RELATIONS}

Julian, as a political speaker, organizes his political text in a particular way in order to persuade others and create political groups that will follow him. In this study, we concentrate on two rhetorical relations (solutionhood and contrast) that contribute to Julian's communicative goal.

\section{i) Solutionhood}

In this relation, a situation or method expressing full or partial satisfaction of a need is presented in the nucleus and a question, request, problem or other expressed need in the satellite. The solutionhood brings to the surface the stylistic strategy of the orators to combine questions with particular answers, in an attempt to motivate the audience and persuade it about what they say. The combination of the directive speech acts with representative ones is an element of the orator's involvement into his text production.

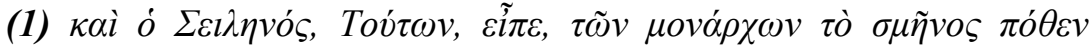

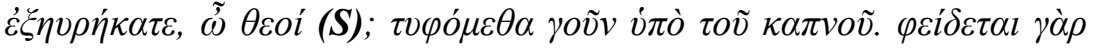

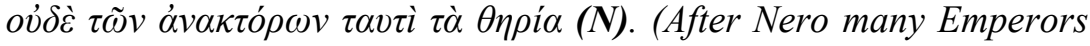
of many sorts came crowding in together, Vindex, Galba, Otho, Vitellius, so that Silenus exclaimed, "Where, ye gods, have yet found such a swarm of monarchs (S)? We are being suffocated with their

and declarations: speech acts that change the reality in accordance with the proposition of the declaration.

${ }^{8}$ For Critical Discourse Analysis see van Dijk (1999-2001), Fairclough (1992-2000), Fairclough \& Wodak (1997). 


\section{A LINGUISTIC APPROACH OF FLAVIUS CLAUDIUS JULIANUS' POLITICAL SATIRES}

smoke; for brutes of this sort spare not even the temple of the gods (N).)

In this example, Silenus through his question motivates with a directive speech act, in the Satelite (S), both the gods and the audience to think and give a solution to the theoretical problem about the emperors and their values. Simultaneously, the Nucleus ${ }^{9}(\mathrm{~N})$ with a representative speech act provides us with a particular answer; Silenus ${ }^{10}$ implies that these emperors committed a lot of dishonourable acts and they are responsible for events, such as the fire in the Temple of Zeus. Through this rhetorical relation, Julian tries to divide the society into two groups, as he wants to stimulate the audience's mind and direct it to a particular way of political thinking. His political ideas rely on piety and justice. He is the emperor who loves, respects the gods and knows how to behave. People must recognize his political value and disapprove of anyone who tries to achieve the modification and disappearance of the traditional religion. As a result of this, Julian tries to promote himself through the solutionhood as the person that embodies the model of the ideal emperor.

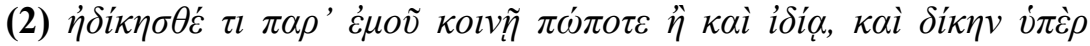

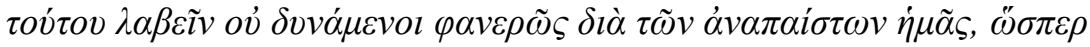

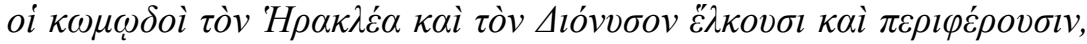

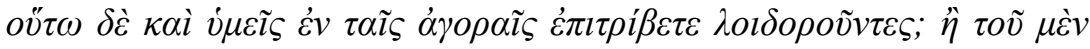

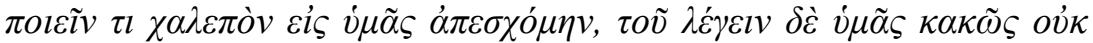

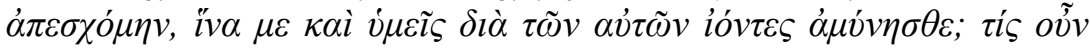

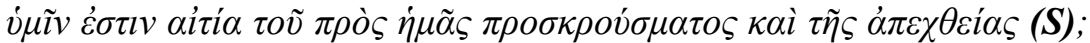

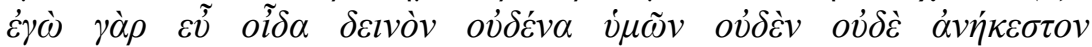

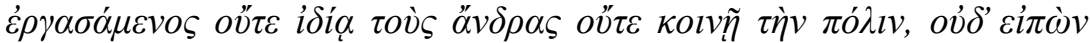

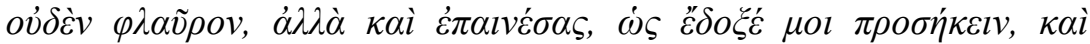

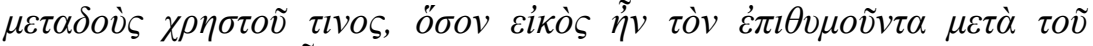

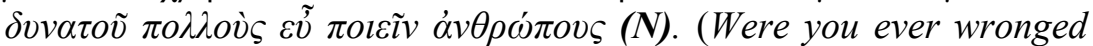
by me in any way, either all in common or as individuals, and is it because you were unable to avenge yourselves openly that you now assail me with abuse in your market-places in anapaestic verse, just as comedians drag Heracles and Dionysus on the stage and make a public show of them? Or can you say that, though I refrained from any harsh conduct towards you, I did not refrain from speaking ill of you, so that you, in your turn, are defending yourselves by the same methods? What, I ask, is the reason of your antagonism and your hatred of me (S)? For I am very sure that I have done no terrible or

\footnotetext{
${ }^{9}$ Nucleus (N) is the more central span and Satellite (S) is the less central one in a text. ${ }^{10}$ Silenus is supposed to be Julian. Through this person Julian criticizes the previous emperors and creates a suggestive comparison between himself and them.
} 


\section{VOLUME 8}

incurable injury to any one of you, either separately, as individuals, or to your city as a whole; nor had I uttered any disparaging word, but I even praised you, as I thought I was bound to do, and bestowed on you certain advantages, as it was natural for one who desires, as far as he can, to benefit many men (N).)

(Misopogon 366b-366d)

In the above example, Julian with several directive speech acts in the satelite directs the audience to a theoretical problem with reference to their ingratitude and dislike towards him. Julian in the nucleus, mostly with representative speech acts, promotes his political ego, as he claims that he did his best for the improvement of the city of Antioch. It is also worth mentioning that in the nucleus he uses the personal pronoun $(\dot{\varepsilon} \gamma \grave{\omega} / I)$ accompanied by an epistemic verb ( $\varepsilon \tilde{v}$ oi $\delta \alpha / I$ am very sure), in order to promote himself as the only person who knows how much he tried to change the political situation in Antioch. He is the person who tried to benefit everyone; however, his mode of life was neglected and satirised by the Antiocheans. As an emperor, he did not allow people to sell their wine and vegetables and fruit for gold, or the corn, which had been locked away by the rich in their granaries to be suddenly converted into silver and gold for their own benefits. For this reason, through the solutionhood Julian tries to promote himself once again instead of the Antiocheans, who ignore the law, the gods and are addicted to immoral values because of their levity.

\section{ii) Contrast}

According to Mann and Thompson, contrast is a multi-nuclear rhetorical relation with no more than two nuclei. The situations presented in these two nuclei are (a) comprehended as the same in many respects, (b) comprehended as different in a few respects, and (c) compared with respect to one or more of these differences.

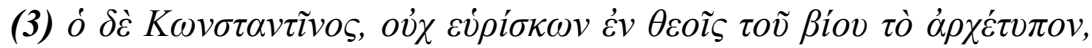

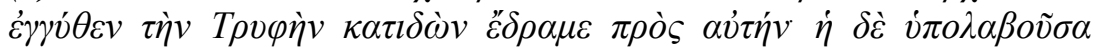

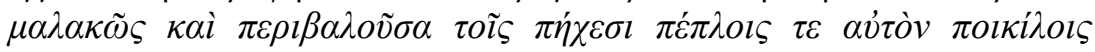

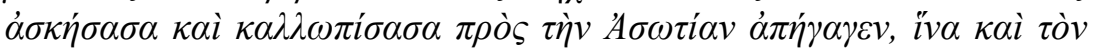

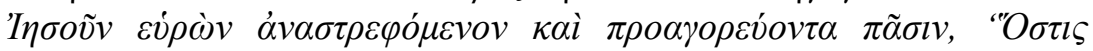

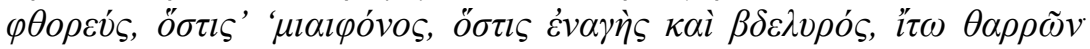

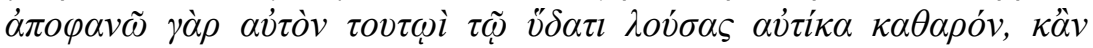

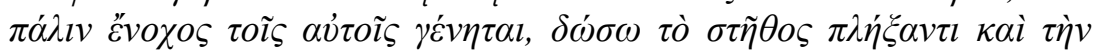

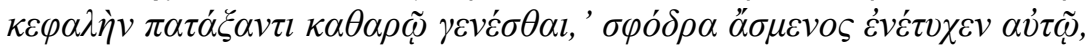

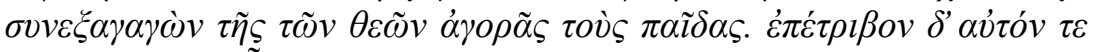

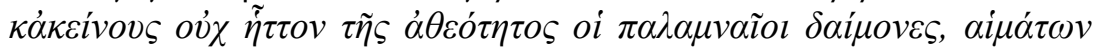

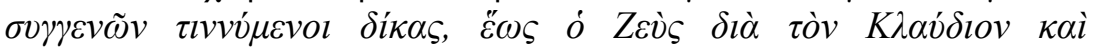




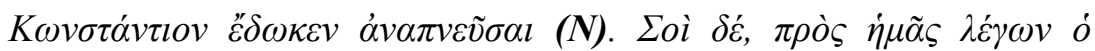

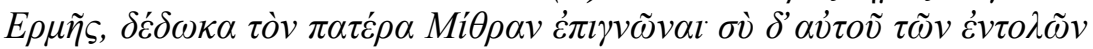

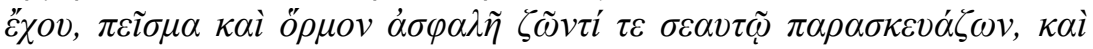

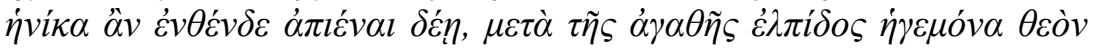
$\varepsilon \dot{\mu} \mu \varepsilon v \tilde{\eta} \kappa \alpha \theta l \sigma \tau \grave{\alpha} \varsigma \sigma \varepsilon \alpha v \tau \tilde{\omega}(\mathbf{N})$. (As for Constantine, he could not discover among the gods the model of his own career, but when he caught sight of Pleasure, who was not far off, he ran to her. She received him tenderly and embraced him, then after dressing him in a variety of many colours and likewise making him handsome, she led him away to Incontinence. There too he found Jesus, who had taken up his abode with her and cried aloud to all comers: "He that is a seducer, he that is a murderer, he that is sacrilegious and infamous, let him approach without fear! For with this water I will wash him and will straightway make him clean. And though he should be guilty of those same sins a second time, let him but smite his breast and beat his head and I will make him clean again." To him Constantine came gladly, when he had conducted his sons forth from the assembly of the gods. But the avenging deities none the less punished both him and them for their impiety, and extracted the penalty for the shedding of the blood of their kindred, until Zeus granted them a respite for the sake of Claudius and Constantius (N). "As for thee", Hermes said to me, "I have granted you the knowledge of thy father Mithras. Do thou keep his commandments, and thus secure for thyself a cable and sure anchorage throughout thy life, and when thou must depart from the world that canst with good hopes adopt him as thy guardian god (N).")

(Caesars 336a-336c)

In this example, it could be said that Julian uses the rhetorical relation of contrast (in macrostructure) for the organization of his thought, because his main goal is to compare himself with Constantine. Through the nucleus of this relation, he also tries to make a contrast between the traditional religion and Christianity. Two Gods, two religions, two emperors are compared. This comparison does not only lead the audience to think about it, but also contributes to the division of the society into two groups, the Paganists, who believe in piety, and the Christians, who have immoral values and delegates. As a conclusion, we understand that Julian through the contrast and satire promotes himself as the ideal emperor. The only thing that remains is to gain supporters, who will believe in him in order to achieve the social, political and religious reconstruction and reform.

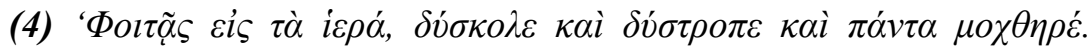

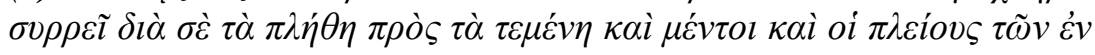




\section{VOLUME 8}

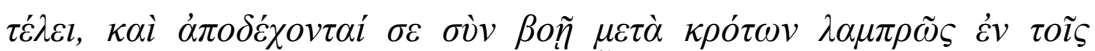

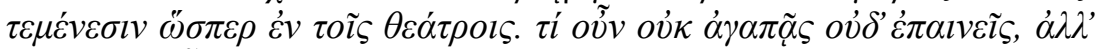

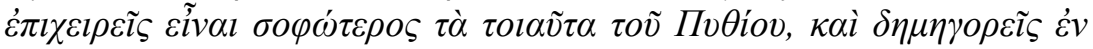

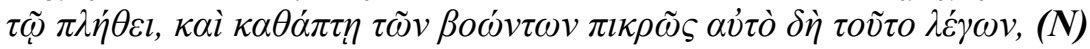

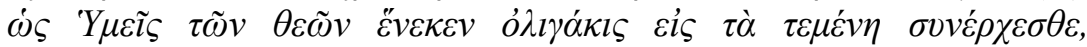

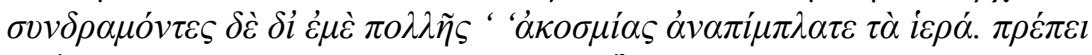

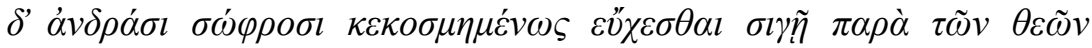

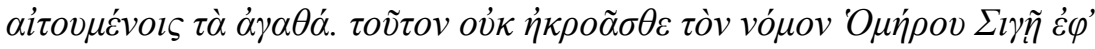

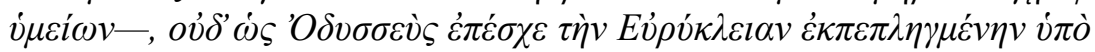

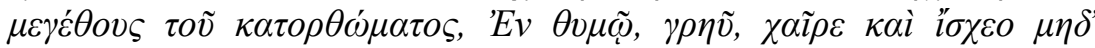

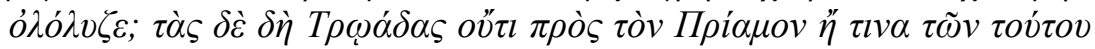

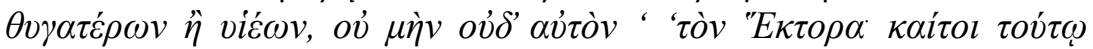

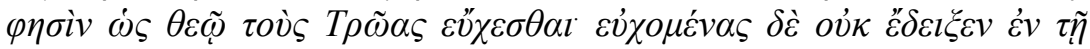

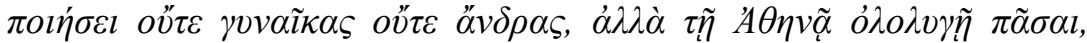

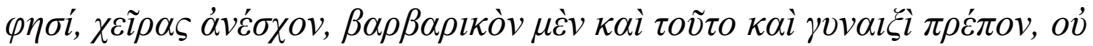

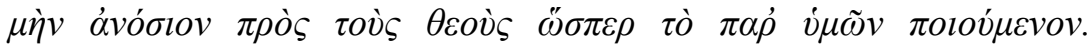

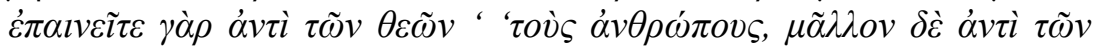

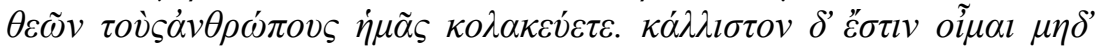

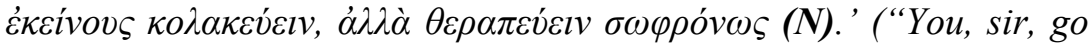
regularly to the temples, ill-tempered, perverse and wholly worthless as you are! It is your doing that the masses stream into the sacred precincts, yes and most of the magistrates as well, and they give you a splendid welcome, greeting you with shouts and clapping in the precincts as though they were in the theatres. Then why do you not treat them kindly and praise them? Instead of that you try to be wiser in such matters than the Pythian god, and you make harangues to the crowd and with harsh words rebuke those who shout $(\mathbf{N})$. These are the very words you use to them: 'You hardly ever assemble at the shrines to do honour to the gods, but to do me honour you rush here in crowds and fill the temples with much disorder. Yet it becomes prudent men to pray in orderly fashion, and to ask blessings from the gods in silence. Have you never heard Homer's maxim, "In silence, to yourselves" -, or how Odysseus checked Eurycleia when she was stricken with amazement by the greatness of his success, "Rejoice, old woman, in thy heart, and restrain thyself, and utter no loud cry"? And again, Homer did not show us the Trojan women praying to Priamus or to any one of his daughters or sons, nay not even to Hector himself (though he does indeed say that the men of Troy were wont to pray to Hector as a god); but in his poems he did not show us either women or men in the act of prayer to him, but he says that to Athene all the women lifted up their hands with a loud cry, which was in itself a barbaric thing to do and suitable only for women, but at any rate it displayed no impiety to the gods as does your conduct. For you applaud men instead of the gods, or rather instead of the gods you 
flatter me who am a mere man. But it would be best, I think, not to flatter even the gods but to worship them with temperate hearts $(\mathbf{N})$.'”)

In example (4) two nuclei and two voices into direct speech are compared. Julian, in the first nucleus, presents to us the Antiocheans' opinion about him and then, in the other nucleus, he analyzes his own opinion about the Antiocheans once again in direct speech. The Antiocheans and Julian compete with each other like being in a battle. Julian's political goal is to express his political ideas and castigate the morals of the Antiocheans. In this way, he promotes himself as the ideal emperor for Antioch, as he is an emperor who has a wide knowledge of philosophy and respects the Gods. Dissapointed by the social and political situation in Antioch, he tries through this satire to change the Antiocheans and direct them to a new way of life, imbued with love for justice and the gods.

Based on the above examples from the satires Misopogon and Caesars, we observe that Julian organizes his arguments through the examined rhetorical relations, solutionhood and contrast, as a means to promote himself and his ideas. Through them, he tries to divide people and gain more political and ideological supporters. The rhetorical relation of solutionhood, with questions of a directive character, manipulates the audience's way of thinking and the answer reveals Julian's political opinion. The rhetorical relation of contrast eluminates two entities to be compared in the text. In this way, Julian exposes the negative intentions of the opponents and produces a negative image of them. Both the examined rhetorical relations harm his opponents and support the political speaker and text producer, as he emphasizes on the positive characteristics of his political and ideological party. His political egotism leads him to the aforementioned usage of rhetorical relations, as he believes that he is the only person who can operate like a political compass for his empire. It is his political goal that leads him to organize his thought in this way and through these rhetorical relations to aim at social change. Julian, as a text producer, organizes his rhetorical structure in such a way because of the power relations governing the production of the political text.

\section{3) INTERTEXTUALITY}

At this point, the way that intertextual sources are included into the Julian's satires is going to be examined, in order to define their new rhetorical functions.

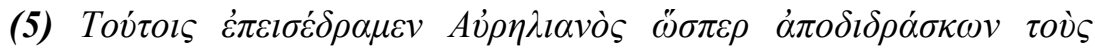

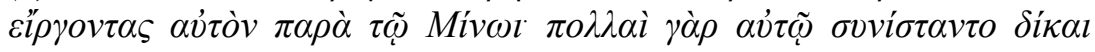

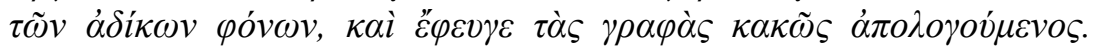




\section{VOLUME 8}

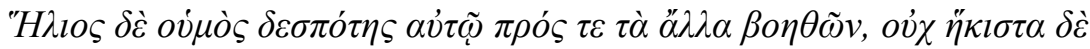

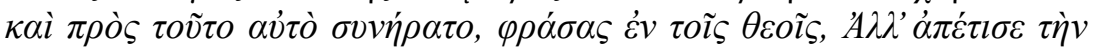

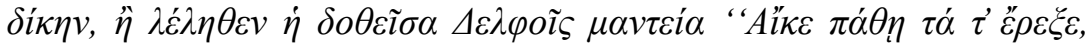

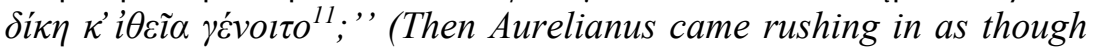
trying to escape from those who would detain him before the judgement seat of Minos. For many charges of unjustifiable murders were brought against him, and he was in flight because he could ill defend himself against the indictments. But my lord Helios who had assisted him on other occasions, now too came to his aid and declared before the gods, "He has paid the penalty, or have you forgotten the oracle uttered at Delphi, 'If his punishment match his crime justice has been done'?")

(Caesars 313d-314a)

In this example from the satire Caesars, Aurelianus does not pay the penalty, because of his piety and dedication to the god Helios. The god Helios defends him before the gods, as a gift for Aurelianus' dedication. The intertextual source into quotation marks acquires new functions, since it adopts the new situational conditions of the new context. The intertextual source helps the speaker promote his political and religious thought, according to which gods help wishful people and forgive their mistakes.

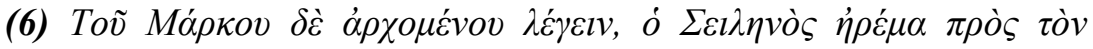

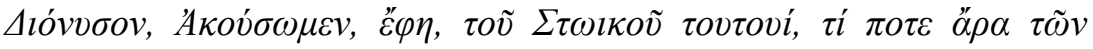

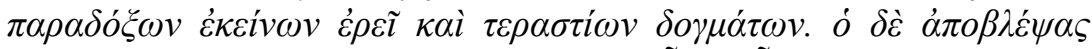

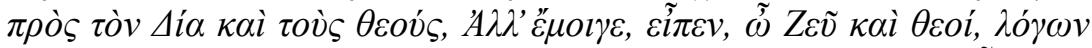

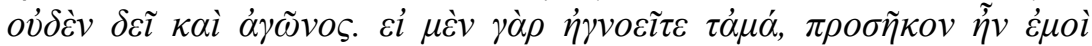

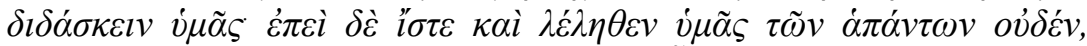

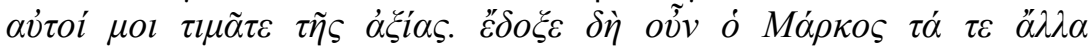

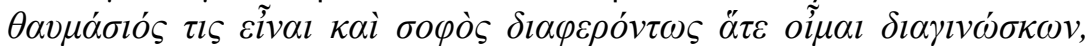

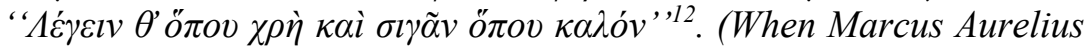
began to speak, Silenus whispered to Dionyssus, "Let us hear which one of his paradoxes and wonderful doctrines this Stoic will produce." But Marcus turned to Zeus and the other gods and said, "It seems to me, Oh Zeus and you other gods, that I have no need to make a speech or compete. If you did not know all that concerns me it would indeed be fitting for me to inform you. But since you know it and nothing at all is hidden from you, do you of your own accord assign me such honour as I deserve." Thus Marcus showed that admirable as he was in other respects he was also wise beyond the rest, because he knew "When it is time to speak and when to be silent.")

${ }^{11}$ An oracular verse ascribed to Rhadamanthus by Aristotle, Nic. Ethics 5. 5. 3; attributed to Hesiod, Fragments 150 Goettling; it became a proverb.

${ }^{12}$ Eyripides, fr. 417 Nauck. 
In the above example, Marcus Aurelius, standing before the gods, tries to persuade them about the value of his character not based on heroic deeds, as he knows that gods know everything. The reason that enables him to gain this divine court is his self-awareness. Julian tries to justify the attitude of Marcus

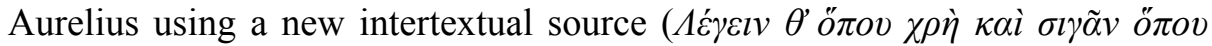
$\kappa \alpha \lambda o ́ v)$. Besides justification, Julian promotes the model of the ideal emperor. This source, into quotation marks, acquires new properties and functions, as the speaker reveals his thought about the ideal emperor. The ideal emperor knows how to handle several situations and respects the gods. In addition to this, it is obvious that Julian uses the verb oĩ $\mu \alpha l$ (think) in order to express his opinion and consequently inform us that he knows how to recognize the elements of political virtue and disapproves of everyone who ignores them. In this way, the praise of Marcus Aurelius is an indirect praise of the speaker and the audience understands that it must follow Julian as the person who has acquired and implemented them in his theoretical and practical life.

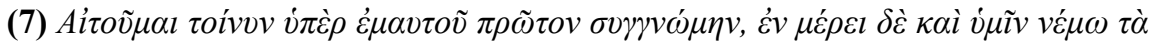

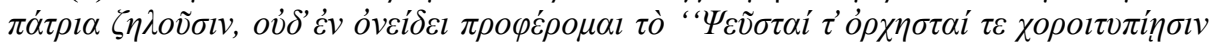

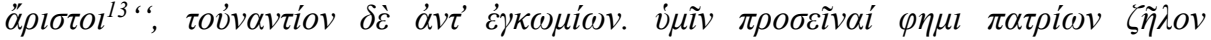

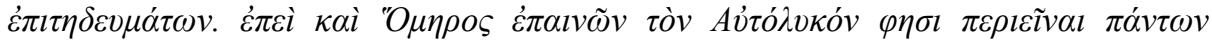

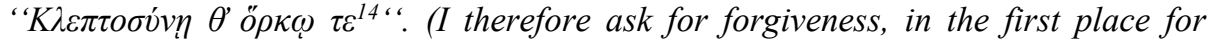
myself, and in my turn I grant it to you also, since you emulate the manners of your forefathers, nor do I bring it against you as a reproach when I say that you are "Liars and dancers, well skilled to dance in a chorus"; on the contrary it is in the place of a panegyric that I ascribe to you emulation of the practice of your forefathers For Homer too is praising Autolycus when he says that he surpassed all men "in stealing and perjury".)

(Misopogon 348d-349a)

In example (7), Julian introduces a new intertextual source ( ' $\Psi \varepsilon \tilde{v} \sigma \tau \alpha i$ ' $\tau$ '

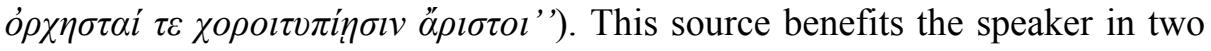
ways; firstly, he defines and disapproves of the Antiocheans' behavior with words, such as Liars and dancers, and secondly he promotes himself as the emperor who forgives his people even though they have insulted him and have behaved in an immoral way because of their levity. Besides these, he uses another intertextual source as evidence to his speech, since he appeals to Homer who did the same in his epos.

${ }^{13}$ Iliad 24.261.

${ }^{14}$ Odyssey 19.396. 


\section{VOLUME 8}

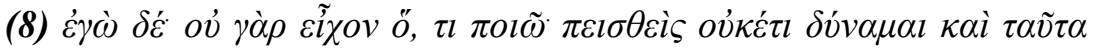

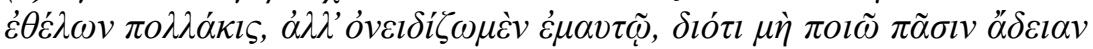

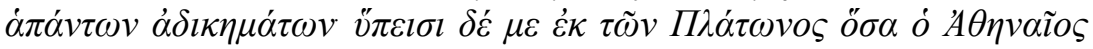

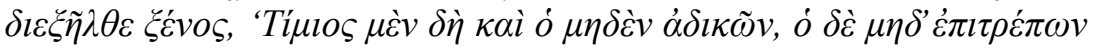

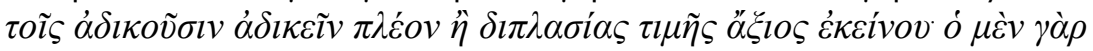

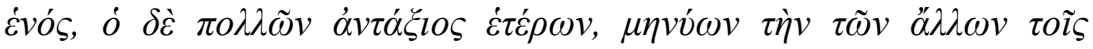

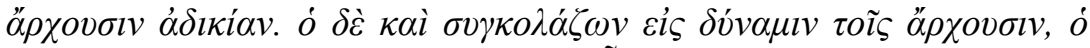

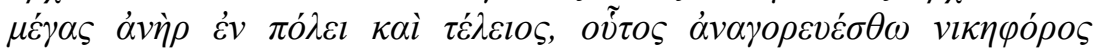

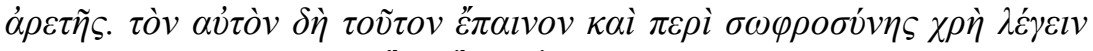

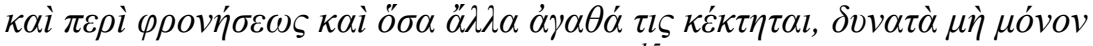

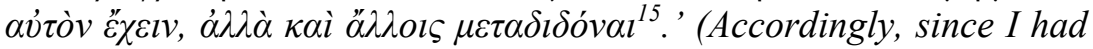
no choice in the matter, I obeyed him, and now I am no longer able to change my character, though indeed I often wish I could, and I blame myself. But then the words of the Athenian stranger in Plato occur to my mind: "Though he who does no wrong himself is worthy of honour, he who does not allow the wicked to do wrong is worthy of more than twice as much honour. For whereas the former is responsible for one man only, the latter is responsible for many others besides himself, when he reports to the magistrates the wrong-doing of the rest. And he who as far as he can helps the magistrates to punish wrong-doers, himself being the great and powerful man in the city, let him I say be proclaimed as winner of the prize for virtue. And we ought to utter the same eulogy with regard to temperance also, and wisdom and all the other good qualities that such a man possesses, and which are such that he is able not only to have them himself but also to impart them to other men.")

(Misopogon 353c-354a)

In the above example, Julian tries to persuade the audience, as regards the reasons that lead him not to be tolerant with impunity. Besides the justification, his main purpose is to reveal his political approach through the intertextual source and disapprove indirectly of the Antiocheans' attitude. His philosophical background does not permit him to be tolerant with people who provoke problems and obstruct him in the execution of his duties.

Even though his rhetorical and political discourse techniques had influence on the behavior of the Antiocheans, he did not change his mind when he decided to leave this city. Antiocheans tried to persuade him to come back, but he did not, as he had lost his confidence and was deeply sad due to their insults.

All in all, it is noted that the incorporation of the intertextual sources into Julian's political satires acquires new functions (self-praise, antithesis,

15 Plato, Laws 730D. 
justification and proof/evidence) as a corollary of their re-contextualization. On the one hand, Julian tends to justify his behavior and gives evidence when setting the intertextual source into quotes, but on the other hand, his main purpose is to promote himself and his political ideology. The intertextual sources serve this purpose, as they are integrated into the new context. The new context comes to help Julian praise himself, in an attempt to gain more supporters. This happens because, as Linell (1998:145) supports, "selected parts of the discourses and their former meanings, 'quoted' as discourse-incontext, are used as resources to create new meanings in the 'quoted' text and its communicative context'.

It is also obvious that in some examples (5, 7 and 8) Julian prefers to define the subject ( $\dot{\eta} \delta o \theta \varepsilon \tilde{i} \sigma \alpha \Delta \varepsilon \lambda \varphi o \tilde{\iota} \varsigma \mu \alpha v \tau \varepsilon i \alpha$, $\dot{\varepsilon} \kappa \tau \tilde{\omega} v \quad \Pi \lambda \dot{\alpha} \tau \omega v o \varsigma \quad \check{\sigma} \sigma \alpha \dot{o}$

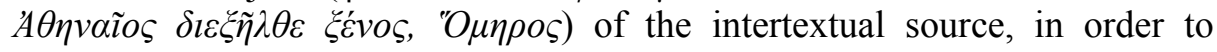
provide more prestige to his speech and display his wide knowledge. In cases where he does not mention the source, this may happen because he knows that the audience has a classical culture and studies and can recognize where the sources comes from. Instead of his rhetorical and political speeches ${ }^{16}$ Julian combines the function of the emphasis with citations in quotation marks. This time Julian resorts to the above rhetorical practice as he wants to praise himself. Through the quotation marks he serves his purpose, in his attempt to legitimize his political choices and strategic by giving objectivity to his message.

\section{CONCLUDING REMARKS}

To sum up, Julian's political satires have a dynamism, which comes from the fact that the texts are not separated from the social, ideological and cultural background. Julian, as a political text producer, organizes his speech acts, coherence and intertextuality in such a way so as to give emphasis on his positive aspects. Julian structures his political approach having a particular goal to achieve favorable effects, persuasion and change of the audience's orientation. This enables us to claim that his rhetorical configuration and his implicit ideological meanings are based on involvement and recontextualization.

\section{REFERENCES}

Alexandropoulos, G. (2013). Text and context in Flavius Claudius Julian's political speeches: coherence, intertextuality and communicative goal. $\mathrm{PhD}$ Thesis. University of Athens. Munich: Lincom.

Athanassiadi, P. (1992). Julian: an intellectual biography. London: Routledge.

16 The function of emphasis in Julian's political speeches is combined with paraphrases (Alexandropoulos 2013: 197). 


\section{VOLUME 8}

Bakhtin, M. (1981). Discourse in the Novel. In: Holquist, M. (ed.), The Dialogic Imagination. Austin: University of Texas Press.

Bakhtin, M. (1986). Speech Genres and Other Late Essays. (Trans. by Vern W. McGee). Austin: University of Texas Press.

Bakhtin, M. (1993). Toward a Philosophy of the Act. (Ed. V. Liapunov and M. Holquist. Trans. Vadim Liapunov). Austin: University of Texas Press.

Baker-Brian, N. \& S. Tougher (2012). Emperor and Author: The Writings of Julian the Apostate. Swansea: Classical Press of Wales.

Bazerman, Ch. \& P. Prior (2004). What Writing Does and How It Does It. NJ: Erlbaum.

de Beaugrande, R. \& W. Dressler (1981). Introduction to Textlinguistics. London: Longman.

Bouffartigue, J. (1992). L'empereur Julien et la culture de son temps. Collection des Études Augustiniennes. Série Antiquité 133.

van Dijk, T. A. (1999). Towards a Theory of Context and Experience Models in Discourse Processing. In: van Oostendorp, H. \& S. Goldman (eds.), The Construction of Mental Representations during Reading. Hillsdale, NJ: Erlbaum, $123-48$.

van Dijk, T. A. (2001). Discourse, Ideology and Context. Folia Linguistica XXX (12): $11-40$.

Fairclough, N. (1992). Discourse and social change. Cambridge: Polity Press.

Fairclough, N. (2000). Discourse, social theory, and social research: the discourse of welfare reform. Journal of Sociolinguistics 4 (2): 163-195.

Fairclough, N. \& Wodak, R. (1997). Critical discourse Analysis. In: van Dijk T. A. (ed.), Discourse as Social Interaction. London: Sage Publications, 258-284.

Fouquet, C. (1985). Julien, la mort du monde antique. Paris: Belles Lettres.

Hoey, M. (1993). A common signal in discourse: how the word "reason" is used in Texts. In: Sinclair, J. M., G. Fox \& M. Hoey (eds.), Techniques of Description in Spoken and Written Discourse: A Tribute to Malcolm Coulthard. Taylor \& Francis, London.

Hunger, H. (1978). Die hochsprachliche profane Literatur der Byzantiner. Munchen: Beck.

Hymes, D. (1974). Foundations of Sociolinguistics: An Ethnographic Approach. Philadelphia: University of Pennsylvania Press.

Kristeva, J. (1980). Desire in Language. Oxford: Basil Blackwell.

Linell, P. (1998). Discourse across boundaries: on recontextualizations and the blending of voices in professional discourse. Text 18 (2): 143-157.

Mann, W. C. \& S. A. Thompson (1986). Relational propositions in discourse. Discourse Processes 9 (1): $57-90$.

Mann, W. C. \& S. A. Thompson (1988). Rhetorical Structure Theory: towards a functional theory of text organization. Text 8 (3): $243-281$.

Potter, D. S (2004). The Roman Empire at Bay AD180-395. Routledge/New York.

Riffaterre, M. (1978). Semiotics of Poetry. Bloomington \& London: Indiana University Press.

Riffaterre, M. (1983). Text Production. New York: Columbia University Press.

Riffaterre, M. (1990). Compulsory Reader Response: The Intertextual Drive. In: Worton, M. \& Still, J. (eds.), Intertextuality: Theories and Practices. Manchester: Manchester University Press, 56-78. 


\section{A LINGUISTIC APPROACH OF FLAVIUS CLAUDIUS JULIANUS' POLITICAL SATIRES}

Searle, J. (1969). Speech Acts: An Essay in the Philosophy of language. Cambridge: Cambridge University Press.

Searle, J. R. (1979). Expression and Meaning. Studies in the Theory of Speech Acts. Cambridge: Cambridge University Press.

Searle, J. R. (1994). How Performatives Work. In: Harnish, R. M. (ed.), Basic Topics in the Philosophy of Language. London: Harvester Wheatsheaf, 75-95.

Searle, J. R. (1996a). What is a Speech Act? In: Martinich, A. P. (ed.), The Philosophy of Language. Oxford: Oxford University Press, 130-140.

Searle, J. R. (1996b). Indirect Speech Acts. In: Martinich, A. P. (ed.), The Philosophy of Language. Oxford: Oxford University Press, 168-182.

Smith, R. (1995). Julian's Gods. Religion and Philosophy in the Thought and Action of Julian the Apostate. London and New York: Routledge.

Tougher, S. (2007). Julian the Apostate (Debates and Documents in Ancient History). Edinburgh: Edinburgh University Press.

Wright, W. C. (1998). The works of the emperor Julian. London: Loeb Clas. Libr.

Winter, E. (1977). A clause relational approach to English texts: a Study of some predictive items in written discourse. Instructional Science 6/1: 1-92. 